\title{
From People to Community: A Description of the Social Order by Thomas Aquinas. Part 1: Populus, Respublica, Multitudo*
}

\author{
Alexander V. Marey \\ Associate Professor, Faculty of Humanities, \\ Leading Researcher, Centre for Fundamental Sociology, \\ National Research University Higher School of Economics \\ Address: Myasnitskaya str. 20, Moscow, Russian Federation 101000 \\ E-mail: amarey@hse.ru
}

\begin{abstract}
In this article I will analyze the central categories of Thomas Aquinas's social thought, such as a people (populus), multitude (multitudo), and Commonwealth (respublica). The next article (Part 2) will contain an investigation of the categories of a community (communitas), communication, and society (societas). I stress the immediate readiness of the question in existing Thomistic literature. Despite the active investigations of Aquinas's political theory, the social theory remains almost forgotten. The works of Ignatius Th. Eschmann, Yves Congar, and Jeremy Catto represent some exclusions from this assertion, but not one of them has paid enough attention to the terminological peculiarities of Thomistic thought. Between the main results of this work, it is worth to focus on the next aspects of the dissipation of the people's concept, its equalization with the multitude, and the break of the connection between the notions of a people and a Commonwealth. The populus in Thomas's theory loses its political nature ascribed to it by Cicero and Augustin. Having lost its subjectivity, the People convert into an organized multitude united by common territory and the same mode of everyday life. Aquinas ignores the creation of the Commonwealth by the People and establishes a connection of another type between these concepts. According to him, the People is a kind of Aristotelian "materia," while the Commonwealth is the "form." In compliance with the precedential assertion, the Respublica becomes eternal and unchangeable, where only the content-i.e., the People or the multitude-can change. In effect, Aquinas formulates the concept of the proto-State here.
\end{abstract}

Keywords: Thomas Aquinas, social theory, the People, populus, Commonwealth, respublica, multitude

(C) Alexander V. Marey, 2016

(c) Centre for Fundamental Sociology, 2016

DOI: $10.17323 / 1728-192 X-2016-4-162-175$

* The results of the project "Friendship, Trust and Conflict as Basic Concepts of Social Theory," carried out within the framework of the Basic Research Program at the National Research University Higher School of Economics (HSE) in 2016, are presented in this work.

This article is made within the framework of the project of the Russian Foundation for the Humanities (RFH) №16-03-00727/16 "The Conceptions of the Royal Authority in the Kingdom of Castile and Leon of $13^{-14^{\text {th }}}$ Centuries."

I'm grateful to Prof. Alexander Fisun (Karazin State University of Kharkov, Ukraine) for his bibliographic consultations and his always kind attention. 
The Concept of the State remained unknown in Medieval European political theory until at least the beginning of the $14^{\text {th }}$ century. ${ }^{1}$ This situation was created in many respects by the domination in the sphere of political culture by the main antagonist of the State, i.e., the People. It seems clear that the concept of the People (populus) as a political actor is strictly opposite to that of the State. Each of them presupposes political unity and, at the same time, political uniqueness. However, if the State can, in theory, communicate with other States, the People remains unique all of the time. All other communities external to it may be considered as tribes or clans, but never as the People. The People, in turn, constructs a proper sphere of social communication between its members, called the public sphere or the "res publica." The existence of such a sphere presumes, first of all, the direct participation of the citizens in the government and in public affairs, among other things. The State, in turn, absorbs all governmental activity, alienating it from the citizens.

In this article, I will begin the analysis of the central socio-philosophical concepts of St. Thomas Aquinas. I will stress some peculiarities of his terminological apparatus and continue with the changes of the concept of the People, which suffered in his work. According to my position, the theological thought of Aquinas would be considered as one of the first steps towards the crash of Medieval political theory and the birth of Modern Social Philosophy. With that end in view, I will begin with a very brief analysis of the traditional medieval concept of People, then continue with the exposition of the historiographic panorama. I will continue with an attempt to expose the Thomistic paradigm of sociality.

\section{A Brief Introduction}

The main frame of Medieval Social Theory was formulated between the first century BC and the 5 th century AD. ${ }^{2}$ The first point was created by Cicero, who, in his famous treatise On the Commonwealth, defined the People as a multitude of men united by juridical consent and common utility. ${ }^{3}$ This definition already signified an important step forward in comparison with Greek political theory, which did not know a concept of the People (despite St. Augustine's affirmation, a populus was never the same as a demos ${ }^{4}$ ). Instead

1. From this time, according to Otto von Gierke, become possible to meet the concepts of the status reipublicae or status regni in the different texts of the jurists like Bartolo and Baldo or of the political theoreticians like John of Paris, Marsiglio of Padua, etc. (Gierke, 1913: 171, infra 246; Post, 1964: 9-11). Quentin Skinner, with the particular references to F. Ercole, J. Hexter and N. Rubinstein, proposed to move this boundary to the end of the $14^{\text {th }}$ century (Skinner, 1989, 2002). Contra vid. the position presented by Gaines Post, Ernst Kantorowitz, and Joseph R. Strayer who, basing their point of view on the analysis of the Medieval theories of the public law, dated the birth of the State by the midst of $13^{\text {th }}$ century (Post, 1964; Strayer, 1970; Kantorowitz, 1957). But both Skinner and his opponents, who tried to implant the State's concept in the more ancient time, acknowledged that the modern State in the proper sense of this word appeared only in the midst of the $16^{\text {th }}$ century.

2. About the medieval fate of the Ciceronian and Augustinian definitions of the people see the article: (Kempshall, 2001)

3. De re publ.I.XXV.39: Res publica est res populi, populus autem non omnis hominum coetus quoquo modo congregatus, sed coetus multitudinis iuris consensu et utilitatis communione sociatus.

4. Aug. Sermo 218 augm.15: Nichodemus autem, quia nomen est graecum, pluribus notum est, quod ex victoria et populo sit compositum, quia nicos victoria est, demos populus. 
of the model of a closed civil community, which was known as a polis, Cicero proposed an alternative known as a civitas, an open community created by the free consent of its members. The membership here took shape not by the right of blood and soil, but by some factors of external and formal character, such as the citizen being freeborn and accepting some the juristic rules which regulated civil life in the civitas. Thus, when Cicero formulated his definition of the populus, he broke the old spatial limits of the citizenship erected by his Greek predecessors. His populus, I should repeat, was the open formal construction which embraced a whole civil community of some city. However, from the other side, the main characteristics defined by Cicero, such as the rational nature of the populus and the law as its basis, inevitably constricted the boundaries of the populus by the collective of the citizens of one particular city.

This constriction was broken by St. Augustine. The Hipponian bishop severely criticized the definition given by Cicero. According to St. Augustine, the People cannot be united by any agreement on the law because the law is based on justice, and justice, in turn, cannot exist in a pagan society. ${ }^{5}$ So, the Ciceronian definition in the Augustinian conception could be applied only to the Church, considered as a spiritual community united by an idea of the supreme justice. As for the People, Augustine proposed to remove both the juridical consent and the common utility from Cicero's formula, and change it from the concord to objects of common love. ${ }^{6}$

Such changes permitted the taking off of the spatial limits presupposed by Cicero. Indeed, if rational consent meant giving this responsibility to a rather limited number of its members (for making a reasonable agreement, it is essential to discuss its conditions, etc.), the emotional concord could be extended all over the Empire. In fact, it is worth it here to repeat the fact that St. Augustine invented the formula of modern representative democracy (for example, the famous slogan of the 1996 election campaign of Boris Yeltsin was "Vote with your heart!"). Thus, the People, in becoming the real populus, would have one object (res) of the common love, that which Augustine called res publica. Without such an object, the People would be converted to the multitude or, more correctly, to the crowd. ${ }^{7}$

5. De civ.XIX.21: Quapropter ubi homo Deo non servit, quid in eo putandum est esse iustitiae? quando quidem Deo non serviens nullo modo potest iuste animus corpori aut humana ratio vitiis imperare. Et si in homine tali non est ulla iustitia, procul dubio nec in hominum coetu, qui ex hominibus talibus constat. Non est hic ergo iuris ille consensus, qui hominum multitudinem populum facit, cuius res dicitur esse respublica.

6. De civ.XIX.24: $\mathrm{Si}$ autem populus non isto, sed alio definiatur modo, velut si dicatur: "Populus est coetus multitudinis rationalis rerum quas diligit concordi communione sociatus," profecto, ut videatur qualis quisque populus sit, illa sunt intuenda, quae diligit. Quaecumque tamen diligat, si coetus est multitudinis non pecorum, sed rationalium creaturarum et eorum quae diligit concordi communione sociatus est, non absurde populus nuncupatur; tanto utique melior, quanto in melioribus, tantoque deterior, quanto est in deterioribus concors. Secundum istam definitionem nostram Romanus populus populus est et res eius sine dubitatione respublica.

7. De civ.XIX.21: Quocirca ubi non est vera iustitia, iuris consensu sociatus coetus hominum non potest esse et ideo nec populus iuxta illam Scipionis vel Ciceronis definitionem; et si non populus, nec res populi, sed qualiscumque multitudinis, quae populi nomine digna non est. 
The Ciceronian and the Augustinian definitions determined the populus's conceptual frame from the Middle Ages until the $17^{\text {th }}$ century. It is quite enough to remember the famous definition of the State made by Thomas Hobbes in the 1660 revised English edition of his Leviathan, writing that this "is more than Consent, or Concord; it is a reall Unitie of them all, in one and the same Person, made by Covenant of every man with every man" (Hobbes, 2010: II.17). The concepts of the Consent and Concord are easily identified with the formulae of Cicero and Augustin.

Thus, the People was the political subject formed by the Republican or, what was the same, by the Imperial organisation. The alternative interpretation of the People's concept presupposed the same essence-Populus Romanus Christianus-but in another form, i.e., the Christian Church. However, another paradigm of political thought arose from the last third of the $13^{\text {th }}$ century. The struggle between the Popes and Empire (known as the fight for the Investiture) ended de facto with the temporary victory of the Pontiffs. The last strong emperor, Friedrich II the Sicilian, died around 1250, and his successors could not withstand the ecclesiastical attack. At the same time, it was possible to mark the rise of the new kingdoms and, from another side, the fast development of Italian and Dutch cities. The new socio-political reality, not yet conditioned by unity but, on the contrary, being familiar with the plurality of the political subjects, needed a new language to describe an emerging social order. It was also connected with the rise of the universities and the rediscovery of Aristotelian philosophical works, most important of which in this context was the Politica, translated into Latin by Willhelm of Moerbeka around 1270. Aristotelian political logic was based on another philosophy than the Ciceronian or the Augustinian schools of thought, and this difference certainly had a significant influence upon the conceptions of the commentators of Stagirit's texts, beginning with Aquinas's thoughts.

\section{Historiography}

Taking the total number of the investigations dedicated to the various aspects of the Thomistic philosophy into consideration, it seems strange that the social theory of Thomas Aquinas was the object of only a few studies in the history of theological and political thought. One of the first authors who turned his attention towards the concept of society developed by Aquinas was Ignatius Theodor Eschmann (O.P.) (1898-1968), an eminent scholar and interpreter of Thomistic thought. In 1949, he became one of the first editors of the English translation of De Regno, where Gerard B. Phelan's translation was revised and completed by Eschmann's foreword and commentaries (Thomas Aquinas, 1949). Two years before, Eschmann had published a two-part article on the social philosophy of Aquinas and, more concretely, on the concept of society (Eschmann, 1946, 1947). It is worth noting that Eschmann's methodological approach devoted more attention to the theological aspects of the problem than to the terminological ones. The concept of society that he studied in the works of Thomas Aquinas was, in effect, created by Eschmann himself and he, it seems, did not pay enough attention to the lexical analysis of 
St. Thomas's texts. That Eschmann did not realize a complete examination of the concept of society as itself in the Aquinas's theory is especially important. Some 30 years later, in 1974, an article was published by another Dominican researcher, the famous theologist and historian Yves Congar (O.P.) (1905-1995) (Congar, 1974). Congar showed the conceptual architecture of the formula populus Ecclesiae within the works of St. Thomas in the framework of his investigation. Despite some exciting and stimulating conclusions, I cannot agree with Congar's central theme since he equates the concept of the People in the Thomistic texts with other terms, such as collegium, congregatio, collectio, etc. This is a serious methodic error, because a congregation and so on can signify only some meeting or an assembly of men, while the populus may represent the political personality, some the corpus politicum, which are different things, in my opinion.

In an article published almost at the same time, Jeremy Catto in Past and Present highlighted the connection between Aquinas's socio-political theory and his practical experience (Catto, 1976). Catto stressed the conceptualization of the term communicatio by Albert the Great and Aquinas himself. According to Catto, this concept was initially used by Robert Grosseteste to translate an Aristotelian word koเvwvía from Greek into Latin. Later the term communicatio entered into the philosophical and theological dictionaries of Albert and his great disciple, where it was used for describing the "bonds of the association," the necessary foundation of each society (Catto, 1976:10). As with the Yves Congar article, I have found some discrepancies with Catto's conception, beginning in the field of terminological analysis. I think that his interpretation of the term "societas" as some organized human multitude is erroneous with respect to Thomas Aquinas. For Aquinas, as I will show later in this paper, this concept signified the communication process, not the human congregation, but that in itself has resulted in the creation of some community.

Finally, 30 years later, in 2007, Nicholas Aroney centred his attention on some of the peculiarities of Aquinas's political theory concerning its principal concepts, i.e., the regnum, provincia, and civitas (Aroney, 2007). The author stressed the problem of the subsidiarity of the political orders and, maybe, for this reason, did not gave enough attention to the conceptual analysis. Aroney extended the Thomistic political philosophy to the Empire, although Aquinas almost never mentioned this form of political order in his writings. Moreover, as J. Catto and other researchers have observed earlier (Catto, 1976: 8; Stetzura, 2010: 38-42), Thomas's political sympathies were on the side of the Papacy, as he tried to not be involved in the relations between the emperor and the Pope. This notwithstanding, Aroney equates the concepts of the communitas and the empire, using Aquinas's constructions of the first to confirm his ideas about the second.

Some minor but interesting commentaries made to the text of the treatise De Regno by one of its translators, Gerald Bernard Phelan (1892-1965) (Thomas Aquinas, 1949), should be added to this brief list. In his translation of the above-mentioned work of Aquinas, Phelan marked some key concepts of the Thomistic social and political philosophy, such as the multitudo, communitas, and civitas. Thanks to the genre of his text-this was the commented translation from Latin into English-Phelan paid more attention to the purely terminological aspects of the problem, explaining his choice of one or another 
word. From another side, the extremely abbreviated format of the commentary did not give G. B. Phelan an opportunity to give his point of view on Aquinas's social theory.

This being said in total allows for the affirmation that Thomas Aquinasa social theory needs a new description. Such analysis, in turn, should begin with the review of the main concepts used by the Dominican scholar for explaining the crucial categories of sociality.

\section{Populus and Respublica}

I will begin the analysis of Aquinas's social terminology with the concept of "populus." This word is one of the most often used in his vocabulary, which makes its analysis rather boring. The quantity of quotations containing the word populus is more than 1,700, not including the more than 1,000 citations of the other authors using this term. ${ }^{8}$ It is significant that more than two-thirds of the quotations containing the term populus is used in the objective cases (first in Genitive, then Dative and Accusative). The use of this term in the Nominative case is relatively rare and, in turn, the major part of these contexts is accompanied by the verbs in the passive voice. It suggests, that for St. Thomas, the populus was the object of the judgement rather than an active and perceptive subject, what was common for almost all of ancient political theory. From the other side, a frequent use of populus along with an absence of its definition in Aquinas's texts (the unique exception is analyzed in some lines below), makes the People in his social theory a sort of empty set, a concept with almost-lost meanings. ${ }^{9}$

Among other mentions of People by Aquinas, the most famous, without doubt, is his definition of populus that figures in the first part of the Theological Summa. According to this formula, the People is the human multitude organized towards some order ${ }^{10}$ and, as Aquinas added in another place, united by the same territory of inhabitation, the unity of its laws, and the mode of its life. ${ }^{11}$ This is the unique, formal definition that St. Thomas gives to the People. In some other cases, he repeats the same thought in other words (multi homines unus populus dicuntur), ${ }^{12}$ but always has the objective to describe, but not to define, the People. This is entirely apparent from the passage of the first part of Summa Theologiae, where Aquinas equates the concepts of the populus, exercitus and collegium

8. All the calculations were made on the base of the search machine of the Corpus Thomisticum (www. corpusthomisticum.org/it/index.age).

9. The indirect confirmation of this point can be found in the famous Lexicon of the Aquinas's works (Schütz, 1895), which does not include any mention of the populus.

10. ST, I, q. 31 a. 1 ad 2: Ad secundum dicendum quod nomen collectivum duo importat, scilicet pluralitatem suppositorum, et unitatem quandam, scilicet ordinis alicuius, populus enim est multitudo hominum sub aliquo ordine comprehensorum. Quantum ergo ad primum, hoc nomen Trinitas convenit cum nominibus collectivis, sed quantum ad secundum differt, quia in divina Trinitate non solum est unitas ordinis, sed cum hoc est etiam unitas essentiae. See the interpretation of this text by Yves Congar (1974).

11. De spiritualibus creaturis, a. 9 ad 10. Ad decimum dicendum quod sicut fluvius Sequana non est hic fluvius propter hanc aquam fluentem, sed propter hanc originem et hunc alveum, unde semper dicitur idem fluvius, licet sit alia aqua defluens; ita est idem populus non propter identitatem animae aut hominum, sed propter eamdem habitationem, vel magis propter easdem leges et eumdem modum vivendi, ut Aristoteles dicit in III Politic.

12. Super Sent., lib. 3 d. 6 q. 2 a. 1 ad 3; ST, I, q. 39 a. 3 co.; Sententia Metaphysicae, lib. 5 l. 8 n. 3 .etc. 
because all three are the different kinds of the human multitude's assembly. ${ }^{13}$ From his practical experience, the Dominican scholar certainly knew about the legislative prerogatives that the people of the different Italian cities sometimes had, but he always restricted himself to mention such possibilities without entering a sophisticated analysis. ${ }^{14}$ In turn, the introduction of the territorial argument made Aquinas's conception of the People entirely different from the precedent of the Ciceronian-Augustinian definitions.

Despite this, Thomas Aquinas sometimes addressed the Ciceronian-Augustinian definition of the People in his works. In these references, he always interpreted the consensus juris as a consent under the Divine Law and not as human positive laws. For example, in the Commentary on the Psalms, and more precisely, the Second Psalm, he affirmed that the People is a "multitudo hominum juris consensu sociata". ${ }^{15} \mathrm{He}$ did it at this particular point to explain that only the Judaic people were really the populus, while the others who did not know the Divine law were gentes, but not the People.

One more exception is the context where the People is considered as a Church. ${ }^{16}$ In this quotation, Aquinas mentions that the meeting of the men who belong to one People can be considered as a political assembly. Thus, the affirmation that the People in its entirety is a sort of a political community is made possible. However, Aquinas never developed such an assumption or discussed the political essence of the People and, as a logical consequence, the question of the People's subjectivity. The authentication of the populus with the Ecclesia served other objectives for him. Speaking about the People-Church, he distinguished the populus Dei or the populus fidelis (either the populus Christianus) from other gentes, or the populi infideli. ${ }^{17}$

13. ST, I, q. 39 a. 3 co. Unde nomina significantia talem formam, si sint substantiva, praedicantur de pluribus in singulari, non autem si sint adiectiva. Dicimus enim quod multi homines sunt collegium vel exercitus aut populus, dicimus tamen quod plures homines sunt collegiati. In divinis autem essentia divina significatur per modum formae, ut dictum est quae quidem simplex est et maxime una, ut supra ostensum est.

14. p.e.: ST, I-II, q. 97 a. 3 ad 3. Si enim sit libera multitudo, quae possit sibi legem facere, plus est consensus totius multitudinis ad aliquid observandum, quem consuetudo manifestat, quam auctoritas principis, qui non habet potestatem condendi legem, nisi inquantum gerit personam multitudinis. Unde licet singulae personae non possint condere legem, tamen totus populus legem condere potest. Si vero multitudo non habeat liberam potestatem condendi sibi legem, vel legem a superiori potestate positam removendi; tamen ipsa consuetudo in tali multitudine praevalens obtinet vim legis, inquantum per eos toleratur ad quos pertinet multitudini legem imponere, ex hoc enim ipso videntur approbare quod consuetudo induxit.

15. Super Psalmo 2, n. 1.: Populus est multitudo hominum juris consensu sociata. Et ideo Judaei dicuntur populus, quia cum lege et sub lege Dei sunt. Alii dicuntur gentes, quia non sunt sub lege Dei. Alii dicuntur gentes, quia non sunt sub lege Dei.

16.Super Sent., lib. 4 d. 20 q. 1 a. 4 qc. 1 co.: Sed in Ecclesia tota est indeficientia meritorum praecipue propter meritum Christi; et ideo solus ille qui praeficitur Ecclesiae, potest indulgentiam elargiri. Sed cum Ecclesia sit congregatio fidelium; congregatio autem hominum sit duplex; scilicet oeconomica, ut illi qui sunt de una familia; et politica, sicut illi qui sunt de uno populo; Ecclesia similatur congregationi politicae, quia ipse populus Ecclesia dicitur.

A detailed investigation on the concept of the Populus ecclesiae in the works of Thomas Aquinas see in the above-mentioned article: (Congar, 1974).

17. Super Sent., lib. 4 d. 4; Super Sent., lib. 4 d. 8; ST, I-II, q. 102 a. 6; ST, II-II, q. 87 a. 1 co.; ST, II-II, q. 99 a. 1 ad 2. etc. 
So, in all other cases, the People in Thomistic social theory serve only as an object which is deficient of any subjectivity, and unable to perform any political action. The people could (and should) be ruled by a king or by princes or priests. ${ }^{18}$ Aquinas sometimes interpreted the People as the king's thing, ${ }^{19}$ stressing this provocative metaphor that the People can be punished for the king's sins, and vice versa, that the king could suffer for the people's sins and crimes. Finally, using the word populus several times, Thomas designated the common People as opposing the aristocracy. ${ }^{20}$

Thus, the People in Aquinas's socio-political theory lost its political subjectivity and became only an object of the cognition. The return of the territorial argument into the conception of populus (est idem populus ... propter eamdem habitationem) planted a bomb with a delayed action under the construction of the Augustinian political conception of the Empire. The People, considered as an organized multitude of human beings, deficient of any political personality and limited by spatial limits, was some of the possibility, or materia in Aristotelian terms. It necessarily required some external political organization or the forma for the conversion from the dynamis to the energeia, from the possibility to the substance. In other words, it required the State, or, in the Aquinas's terminology, the respublica.

Before continuing with the respublica's analysis in Thomas's texts, I should offer one more reservation. It is clear that Aquinas never meant the State in the modern sense of this word. He certainly knew the set expression status regni, but he used it only a few times, and each time in the Commentaries on the Psalms. ${ }^{21}$ With these words, Aquinas mainly expressed the common idea of that time, that political power within the kingdom should belong to the king personally. To describe a wholly political entity, Thomas used exactly the word respublica (naturally, in the sense of the Commonwealth, not the Republic), which I will analyze below.

The concept of respublica in Aquinas's terminology had some remarkable peculiarities. From a socio-political point of view, the respublica, according to Thomas, is a sort of political community. ${ }^{22}$ This is a very broad definition, because in this sense, almost every type of an assembly can be named the respublica, including, for example, the Church, which Aquinas sometimes defined as respublica omnium Christianorum. ${ }^{23}$ The "respubli-

18. ST, I-II, q. 105 a. 1 s.c.; ST, II-II, q. 174 a. 6 ad 2; Quodlibet II, q. 6 a. 1 co.; Quodlibet III, q. 5 a. 2 arg. 5; etc. 19. Super Sent., lib. 2 d. 33 q. 1 a. 2 ad 5; etc.

20. Just for example see the famous definition of democracy taken from the treatise On the Rulership: De regno, I.2: Si vero iniquum regimen exerceatur per multos, democratia nuncupatur, id est potentatus populi, quando scilicet populus plebeiorum per potentiam multitudinis opprimit divites. Sic enim populus totus erit quasi unus tyrannus.

21. Super Psalmo 17, n. 28; Super Psalmo 41, n. 1; Super Psalmo 50, n. 1; about a value and signification of such citatons see Skinner, 2002: 30-31.

22. ST, I-II, q. 100 a. 5 co.: Respondeo dicendum quod, sicut supra dictum est, sicut praecepta legis humanae ordinant hominem ad communitatem humanam, ita praecepta legis divinae ordinant hominem ad quandam communitatem seu rempublicam hominum sub Deo. Ad hoc autem quod aliquis in aliqua communitate bene commoretur, duo requiruntur, quorum primum est ut bene se habeat ad eum qui praeest communitati; aliud autem est ut homo bene se habeat ad alios communitatis consocios et comparticipes.

23. See for example: ST, II-II, q. 187 a. 4 co.; Contra impugnantes, pars 2 cap. 6 co. 
$c a$ " always has its good and its common good ${ }^{24}$ as its final goal ${ }^{25}$, which every member of the community was obliged to defend. As to the political administration of the Commonwealth, it can take diverse forms (for example, the respublica can be ruled by the king or emperor, or prince, or even the people) and does not have any influence upon the community's essence.

From an ontological position, Aquinas defined the respublica as the form, while the group of men represented in this context is the materia. ${ }^{26}$ The Commonweath, according to this formula, is eternal; it was never born and it will never die. All the changes, which can be detected in the respublica, pertain to the temporal, material side, since one man can appear, and another can disappear. Nevertheless, all of these changes cannot affect the eternal form.

Aquinas never said anything about the people's role in the organisation or in the legislation of the respublica. ${ }^{27}$ This fact, along with all that has been aforesaid about the people in his socio-political theory, suggests and even affirms that the respublica was entirely another thing for Thomas than what it entailed, for example, for Cicero and Augustine. He used the same word for express a completely different idea. I think that it is worth to say that Aquinas described a proto-state structure under the name of respublica of which some of the political, spatial order, its borders, its ruler or rulers, and its final goal can be different from the aims of another respublicae. The People, or the multitude, in this case, is only the materia, the inconstant and unsteady content of an eternal form.

\section{Multitudo}

One more category of Aquinas's social thought which deserves to be analyzed, is, without doubt, the multitude or the "multitudo." For later political philosophy, this concept received the crucial importance (it is worth it to remember the Hardt and Negri's book of the same name dedicated to the analysis of the multitudo in Spinozian texts). For Aqui-

24. Super Sent., lib. 4 d. 38 q. 2 a. 4 qc. 1 ad 1; Contra Gentiles, lib. 3 cap. 151 n. 3; ST, I-II, q. 61 a. 5 arg. 4; ST, II-II, q. 32 a. 6 co.; Quodlibet XI, q. 10 a. 2 co.; etc.

25. Contra Gentiles, lib. 3 cap. 144 n. 4; Contra Gentiles, lib. 3 cap. 151 n. 3; Quodlibet XI, q. 10 a. 2 co; etc.

26. Quodlibet VIII, q. 3 co. Ponit enim haec opinio quod utrumque, scilicet et quod ex alimento generatur, et quod a parentibus trahitur, indifferenter et aequaliter forma humana perficitur, et utrumque indifferenter manet vel consumitur; manet quidem secundum speciem, consumitur autem et restauratur secundum materiam. Sicut in aliqua republica diversi homines numero ad communitatem pertinent, quibusdam morientibus, et aliis in locum eorum succedentibus; et sic non manet una respublica secundum materiam, quia sunt alii et alii homines; manet tamen una numero quantum ad speciem sive formam, propter ordinis unitatem in officiis distinctis: ita etiam in corpore humano manet caro et os unaquaeque partium eadem numero quantum ad speciem et formam quae consideratur in determinato situ et virtute et figura; non autem manet quantum ad materiam: quia illa materia carnis, in qua talis forma erat, prius consumpta est, et alia in locum eius successit; sicut patet de igne qui continuatur secundum eamdem formam et modum, per hoc quod consumptis quibusdam lignis alia supponuntur quae ignem sustinent. Et secundum hanc opinionem, de utroque praedictorum indifferenter, scilicet generato ex alimento et a parentibus tracto, tantum resurget, quantum est necessarium ad speciem et quantitatem debitam humani corporis.

See also the same argument in: Super Sent., lib. 4 d. 44 q. 1 a. 2 qc. 4 co.

27. The unique exception is the STh, I-II, q. 97 a. 1 co., where Aquinas cited the Augustine's text. 
nas, in turn, this concept was not so important as a technical term, although Thomas used it frequently (there are more than 3000 occurrences). The largest part of the usage interprets this word in the literal sense, as a "high number of something," but some other cases allow for the making of further observations.

From various ontological positions, every multitudo in Aquinas's theory is formed from diverse unities ${ }^{28}$ and, at the same time, could be reduced to a unity and, sometimes, opposed to it. ${ }^{29}$ Such an interpretation transferred to the field of social theory gives an image of the multitude as a congregation of autonomous individuals, ${ }^{30}$ which, in turn, becomes some sort of a whole.

In Thomas's socio-political language, the multitudo served as one of the principal synonyms for the concept of People. As mentioned above, the populus, according to the definition given by Aquinas, was no more than the human multitude organized towards some order. ${ }^{31}$ In order to make a more penetrating analysis of this word, it seems possible to pick out six additional smaller groups from the citations, each of them containing a one word-combination using the term multitudo: M. humana; M. hominum; M. civilis; M. domestica; M. civitatis; and M. populi. It is worth noting that the combinations like M. regni, M. provinciae, M. imperii or even the M. politica were never used by Aquinas, what indicates, among other ideas, a non-political nature of the multitude, and its pertinence to the pure social sphere.

The concepts of the human multitude (M. humana) and the multitude of men ( $\mathrm{M}$. hominum) are similar enough to allow analyzing them as one. First of all, I will omit all the multiple citations, where the "multitude of men" was used by Aquinas to designate only a large quantity of people but no more. As for the rest, Thomas used the construction multitudo hominum most often to describe the human community. In some texts, he also stressed that all the men within the frame of the multitude are diverse, ${ }^{32}$ and that their goals are also different. However, there were two principal aspects where Aquinas emphasized the unity of the human multitude. The first of these modes of discussion can be defined as "ethical," while the other can be defined as "political."

28. Super Sent., lib. 1 d. 24 q. 1 a. 3 arg. 5: Praeterea, privatio nunquam constituit habitum, nec e converso et similiter nec affirmatio negationem, nec unum contrariorum alterum. Sed multitudo constituitur ex unitatibus. Ergo videtur quod unitas non privet multitudinem, nec e converso.

29. Super Sent., lib. 1 d. 2 q. 1 a. 1 co: Respondeo dicendum, quod cum omnis multitudo procedat ab unitate aliqua, ut dicit Dionysius, oportet universitatis multitudinem ad unum principium entium primum reduci, quod est Deus; hoc enim et fides supponit et ratio demonstrat.

30. See for ex.: Sentencia De sensu, tract. 1 1. 8 n. 9.

31. ST, I, q. 31 a. 1 ad 2, etc.

32. In De divinis nominibus, cap. 12 pr.: ... Per nomen regni datur intelligi non unius tantum directio, sed totius multitudinis humanae, quae quidem non est uniformis, sed habens multas varietates secundum diversas hominum conditiones et diversa officia, quae ad bonum statum multitudinis pertinent, ideo, quamvis sit unus communis totius multitudinis finis, tamen sunt multi et differentes diversorum fines particulares; puta: medici, sanitas; militis, victoria; oeconomici, divitiae; et sic de aliis. Ad consequendum autem diversos fines, necesse est homines diversas facultates habere ex diversis bonis quibus oriuntur et diversis legibus regulari: aliae enim leges imponendae sunt militi; aliae emptori; aliae venditori; et sic de aliis. (see also Sententia Politic., lib. 1 1. 3 n. 5; Sententia Politic., lib. 2 1. 5 n. 6). 
First, the men who form the multitude, says Thomas, have some common points, such as common needs, ${ }^{33}$ a common weakness for temporal and corporal goods, ${ }^{34}$ and, what is more important, common moral imperfections. The multitude, for its major part, consists of imperfect and vicious men, whose circumstances determine the quality of human laws. The latter neither can be bound to high morality actions nor forbid all illicit acts. The human legislation's main goal, according to Aquinas's position, is to forbid only the most harmful actions, allowing, at the same time, some minor offences because any human multitude can hardly exist without them. ${ }^{35}$

On the other hand, within the framework of the interpretation of the human multitude as a political object, Aquinas noticed that it ought to be united by the bonds of peace $^{36}$ and by the enjoyment of Divine goods as a common goal. ${ }^{37}$ If the ties of this kind do not exist, the multitude begins to destroy itself. Without inner peace, the members of the multitude start to persecute one other and, as a consequence, will be afraid of each other. Aquinas does not use the formula bellum omnium contra omnes, but he describes this situation, for example, in his Commentary to the Book of Job, ${ }^{38}$ among other works. The existence of such bonds supposes, on the one hand, the common goal's presence and, on the other, the appearance of the governor of any kind. ${ }^{39}$ The latter is necessary because only the emergence of the political power as some sort of the vis (or virtus) regitiva can transform the multitude into a political object. This assumption is substantiated by Aqui-

33. Contra Gentiles, lib. 3 cap. 136 n. 9: In his autem quae necessaria sunt multitudini, non oportet quod cuilibet de multitudine attribuatur: neque etiam est possibile. Patet enim multa esse necessaria multitudini hominum, ut cibus, potus, vestimentum, domus, et alia huiusmodi, quae impossibile est quod per unum procurentur. Et ideo oportet diversorum esse diversa officia: sicut et in corpore diversa membra ad diversos actus ordinantur. (see also DRG, I.1)

34. Sententia Ethic., lib. 9 1. 8 n. 9: Dicit ergo primo, quod illi qui in opprobrium reputant esse amatorem sui, illos vocant sui amatores, qui tribuunt sibiipsis plus in bonis corporalibus, scilicet in pecuniis, et honoribus, et in delectationibus corporalibus, quales sunt ciborum et venereorum. Huiusmodi enim bona multitudo hominum appetit. Et attendunt ad ipsa homines, ac si essent optima. (see also: Sententia Ethic., lib. 9 1. 12 n. 6; Sententia Ethic., lib. 10 1. 10 n. 12; and Sententia Ethic., lib. 10 1. 13 n. 6).

35. Quodlibet II, q. 5 a. 2 ad 2: Ad secundum dicendum, quod praecepta legis sunt ductiva ad perfectam virtutem: tamen actus perfectae virtutis non cadunt sub praecepto legis humanae; sed prohibet quaedam graviora, ut gradatim homines retracti a malis per seipsos ad virtutem exerceantur. Permittit autem quaedam minora peccata, eis poenam non infligens, quia sine his non facile invenitur hominum multitudo; et de talibus est deceptio quae est inter vendentes et ementes: quia plurimi sunt qui volunt vili emere et care vendere, ut Augustinus dicit in Lib. de Trin. (see also: ST, I-II, q. 96 a. 2 co.)

36. De regno, lib. 1 cap. 16 co.: Secundo, ut multitudo vinculo pacis unita dirigatur ad bene agendum. Sicut enim homo nihil bene agere potest nisi praesupposita suarum partium unitate, ita hominum multitudo pacis unitate carens, dum impugnat se ipsam, impeditur a bene agendo. Tertio vero requiritur ut per regentis industriam necessariorum ad bene vivendum adsit sufficiens copia.

37. De regno, lib. 1 cap. 15 co.

38. Cfr.: Super Iob, cap. 31.

39. Cfr. for example: De regno, lib. 1 cap. 3 co.; Sententia Politic., lib. 1 1. 3 n. 5. 
nas's reference to human nature, which is political, ${ }^{40}$ and by his note on the politic as a directive principle of any human multitude. ${ }^{41}$

Furthermore, the main difference between the simple human multitude and the civil multitude (multitudo civilis) is that the latter is the multitudo ordinata; the same can be said about the domestic multitude or the household, which is the necessary part of the former. ${ }^{42}$ Each ordered multitude, beginning from the human individual, makes part of some other of greater size: so, some persons form the household, from the latter's assembly, in turn, appears the city, the union of the cities creates the province or the kingdom, and so on. Here Aquinas follows Aristoteles, but does not limit himself with the concept of the city or polis, including the whole world can be interpreted in his theory as a wellordered multitude. However it is clear that in Aquinas's theory, the order is not enough for create the political multitude, but it should be completed with the convenient goal. Finally, with the concept of multitudo civitatis, Aquinas always described the population of the city, sometimes stressing its quantity, ${ }^{43}$ in the same way he used the word-combination "citizen's multitude" (multitudo civium), ${ }^{44}$ and the multitudo populi (the latter, certainly, with respect to all the people). ${ }^{45}$

\section{Concluding Remarks}

In concluding this first part of the investigation of Aquinas's social philosophy, I would like to reiterate some points that have a crucial importance for understanding the political and social theory of the great Dominican thinker.

First of all, the introduction of the Aristotelian argument in the theory of the populus broke the old paradigm of political thought represented by Marc T. Cicero and Aurelius Augustin. For Cicero, the people was a sort of civil assembly united by the common sense of justice, while for Augustin, the multitude had some common object of their love. The

40. Sententia Politic., lib. 1 1. 3 n. 5: Quaecumque sunt ex pluribus constituta, in his est aliquid principans et aliquid subiectum naturaliter, et hoc expedit. Sed hominum multitudo est ex pluribus constituta: ergo naturale est et expediens quod unus principetur et alius subiiciatur. Huius autem rationis minor manifesta est ex praemissis: in quibus ostensum est quod homo est naturaliter animal politicum, et ita naturale est quod ex multis hominibus constituatur una multitudo.

41. Sententia Ethic., lib. 6 1. 6 n. 5: Oportet autem esse solam unam sapientiam, quia ad eam pertinet considerare ea quae sunt communia omnibus entibus. Unde relinquitur, quod politica, quae est gubernativa humanae multitudinis, non potest esse sapientia simpliciter; et multo minus prudentia communiter dicta, quae est gubernativa unius.

42. ST, III, q. 8 a. 1 ad 2: Capitis igitur naturalis non est caput aliud, quia corpus humanum non est pars alterius corporis. Sed corpus similitudinarie dictum, idest aliqua multitudo ordinata, est pars alterius multitudinis, sicut multitudo domestica est pars multitudinis civilis. Et ideo paterfamilias, qui est caput multitudinis domesticae, habet super se caput rectorem civitatis. (see also: Sententia Ethic., lib. 1 1. 1 n. 4; Sententia Ethic., lib. 1 1. $1 \mathrm{n} .5$ ).

43. Sententia Politic., lib. 2 1. 5 n. 5; Sententia Politic., lib. 2 1. 5 n. 6; Sententia Politic., lib. 2 1. 7 n. 2; Sententia Ethic., lib. 9 1. 12 n. 5.

44. Sententia Politic., lib. 2 passim.

45. ST, II-II, q. 69 a. 2 ad 1; ST, III, q. 8 o a. 12 co.; Super Isaiam, cap. 9 1. 2; Super Psalmo 3, n. 4; Super I Cor., cap. 11 vs. 7 ; etc. 
Ciceronian beliefs were the foundations for the Republican theory, while the Augustinian philosophy was the basis for political emotionalism and classic imperialistic thought. The social theory of Aquinas gave another view of the populus as the de-subjectified multitude united by the territory and the mode of life. In other words, for Aquinas, the people could be only the materia, while its form was the Commonwealth or respublica.

Furthermore, the concept of "respublica" in Thomas's theory was completely separated from that of the populus. The Dominican theologist never mentioned that the respublica was created by the people or even ruled by it. In fact, the Commonwealth described by Aquinas was some formal spatial order, inside which the populus or the multitudo existed.

It follows that the place occupied by the people in the Ciceronian-Augustinian paradigm remained empty in Thomistic theory. Some other social substance should take up this position of the active social and political subject. As I will show in the next section of this research, this area was occupied by the concept of the communitas.

\section{References}

Aroney N. (2007) Subsidiarity, Federalism and the Best Constitution: Thomas Aquinas on City, Province and Empire. Law and Philosophy, vol. 26, no 2, pp. 161-228.

Catto J. (1976) Ideas and Experience in the Political Thought of Aquinas. Past and Present, vol. 71, no 1, pp. 3-21.

Congar Y. O. P. (1974) "Ecclesia" et "Populus (fidelis)" dans lecclésiologie de S. Tomas. St. Thomas Aquinas, 1274-1974: Commemorative Studies (ed. A. Maurer), Toronto: Pontificial Institute of Mediaeval Studies, pp. 159-174.

Eschmann I. T. O. P. (1946) Studies on the Notion of Society in St. Thomas Aquinas. I. St. Thomas and the Decretal of Innocent IV Romana Ecclesia: Ceterum. Medieval Studies, vol. 8, pp. 1-42.

Eschmann I. T. O. P. (1947) Studies on the Notion of Society in St. Thomas Aquinas. II. Thomistic Social Philosophy and the Theology of Original Sin. Medieval Studies, vol. 9, pp. 19-55.

Gierke O. von (1913) Political Theories of the Middle Ages (ed. F. W. Maitland), Cambridge: Cambridge University Press.

Hobbes Th. (2010) Leviathan (ed. I. Shapiro), New Haven: Yale University Press.

Kantorowicz E. (1957) The King's Two Bodies: A Study in Mediaeval Political Theology, Princeton: Princeton University Press.

Kempshall M. S. (2001) De republica I.39 in Medieval and Renaissance Political Thought. Cicero's Republic (eds. J. A. North, J. G. F. Powell), London: Institute of Classical Studies, pp. 99-135.

Post G. (1964) Studies in Medieval Legal Thought. Public Law and the State 1100-1322. New Jersey: Princeton University Press.

Schütz L. (1895) Thomas-Lexikon. Sammlung, Padeborn: Schöningh.

Skinner Q. (1989) The State. Political Innovation and Conceptual Change (eds. T. Ball, J. Farr, R. Hanson), Cambridge: Cambridge University Press, pp. 90-113. 
Skinner Q. (2002) The State. Ponyatie gosudarstva v chetyrekh yazykah [The Notion of the State in Four Languages] (ed. O. Kharkhordin), Saint Petersburg: EUSP Press, pp. 12-74.

Strayer J. R. (1970) On the Medieval Origins of the Modern State, Philadelphia: Princeton University Press.

Stetzura T. D. (2010) Khozyaistvennaya etica Fomy Akvinskogo [The Economical Ethics of Thomas Aquinas], Moscow: ROSSPEN.

Thomas Aquinas (1949) De regno ad regem Cypri, Toronto: The Pontifical Institute of Mediaeval Studies.

\title{
От народа к общности: описание социального порядка Фомой Аквинским. Часть 1: Populus, Respublica, Multitudo
}

\author{
Александр Марей \\ Кандидат юридических наук, доцент школы философии факультета гуманитарных наук, \\ ведущий научный сотрудник Центра фундаментальной социологии \\ Национального исследовательского университета «Высшая школа экономики» \\ Адрес: ул. Мясницкая, д. 20, г. Москва, Российская Федерация 101000 \\ E-mail: amarey@hse.ru
}

В рамках данной статьи анализируются основные категории социальной философии Фомы Аквинского, такие, как народ (рорulus), совокупность (multitudo) государство/республика (Respublica). В следующей статье (Часть 2) будет представлено исследование понятий общность (communitas/communicatio) и общение (societas). Обращает на себя внимание серьезный дефицит исследовательской литературы по социальной мысли Аквината. Учеными в основном осмысляется политическая мысль великого доминиканца, в то время, как социальная остается практически забытой. Работы И. Т. Эшмана, И. Конгара, Дж. Катто, представляющие собой исключение из этого утверждения, подробно анализируются в статье. Среди основных результатов проведенного исследования можно указать следующие. Во-первых, для философии Фомы характерна десемантизация понятия «народ», которое, по сути, уравнивается в значении с понятием «совокупность», что приводит к потере связи между понятиями народа и республики. Народ в теории Аквината теряет свое политическое значение, характерное для теорий Цицерона и Августина, господствовавших в политико-социальной мысли предшествовавшего периода. Взамен народ определяется как совокупность людей, проживающих на определенной территории и объединенных общими законами и общим образом жизни. В онтологическом смысле, народ определяется Фомой как материя, тогда как Respublica как форма. По сути дела, Аквинат формулирует одну из первых теорий протогосударства.

Ключевые слова: Фома Аквинский, социальная теория, народ, республика, государство, совокупность 